\title{
ANALISIS KEMAMPUAN PEDAGOGICAL AND CONTENT BIOLOGY KNOWLEDGE (PCBK) MAHASISWA PENDIDIKAN BIOLOGI DALAM MERANCANG RENCANA PEMBELAJARAN
}

\author{
Bhakti Karyadi $^{{ }^{*}}$, Alif Yanuar Zukmadini ${ }^{1}$, Neni Muniarti ${ }^{1}$ \\ ${ }^{1}$ Program Studi Pendidikan Biologi Fakultas Keguruan dan Ilmu Pendidikan, Universitas Bengkulu \\ Email: bkaryadi@unib.ac.id
}

\begin{abstract}
Abstrak
Pendidikan calon guru biologi masa depan dihadapkan pada isu integrasi pengetahuan pedagogik dan konten biologi (Pedagogical Content Biology Knowledge/PCBK). Calon guru diharapkan menjadi guru yang terampil mengajar dengan efektif, menguasai materi ajar, dan mampu memanfaatkan teknologi pembelajaran. Analisis data kemampuan PCBK dalam merancang rencana pembelajaran dilakukan secara deskripsi berdasarkan Content Representation dan Pedagogical and ProfessionalExperience Repertoire. Hasil analisis menunjukkan persentase kemampuan mahasiswa Pendidikan Biologi dalam merancang pembelajaran biologi sebagian besar mahasiswa memiliki kemampuan PCBK berkategori cukup sebesar 37,50, sedankan kategori baik dan sangat baik masing masing $28,13 \%$, kategori kurang mencapai 6,25\%, dan tidak ditemukan mahasiswa yang berkategori sangat kurang. Kemampuan mahasiswa dalam menentukan model dan metode pembelajaran, mengembangkan konten materi ajar biologi, dan merancang aktivitas pembelajaran telah mencapai kriteria ketercapaian minimal ( $\geq 70 \%$ ) masing-masing mencapai 74,75\%, 77,50\%, dan 76,25, sedangkan kemampuan merumuskan indikator dan tujuan pembelajaran belum memenuhi kriteria ketercapaian minimal, masing-masing komponen hanya mencapai $63,75 \%$ dan $61,75 \%$. Simpulan penelitian kamampuan secara umum mahasiswa telah mampu merancang rencana pembelajaran dengan baik. Kemampuan mahasiswa dalam merumuskan indikator dan tujuan pembelajaran perlu terus ditingkatkan melalui latihan dan penugasan secara terstruktur.
\end{abstract}

Kata kunci : $P C B K, S P B$

\begin{abstract}
The education of future biology teacher candidates is faced with the issue of integration of pedagogical knowledge and biological content (Pedagogical Content Biology Knowledge / PCBK). Prospective teachers are expected to become teachers who are skilled at teaching effectively, mastering teaching materials, and are able to take advantage of learning technology. The instrument used was an assessment rubric for the preparation of biology learning designs, which consisted of two main components, namely pedagogical knowledge and biological material content. Data analysis on PCBK's ability in designing lesson plans is carried out descriptively based on Content Representation and Pedagogical and Professional-Experience Repertoire. The results of the analysis showed that the percentage of P.BIO students' ability in designing biology learning, most of the students had the ability of PCBK in sufficient categories of 37.50 , while the good and very good categories respectively were $28.13 \%$, the categories were less than $6.25 \%$, and were not found. students who are categorized very less. The ability of students in determining learning models and methods, developing the content of biology teaching materials, and designing learning activities has achieved the minimum achievement criteria ( $\geq 70 \%$ ) respectively reaching $74.75 \%, 77.50 \%$, and 76.25 , while the ability formulating indicators and learning objectives have not met the minimum achievement criteria, each component only reached $63.75 \%$ and $61.75 \%$. In conclusion, students' ability in general have been able to design learning plans well. The ability of students in formulating indicators and learning objectives needs to be continuously improved through structured exercises and assignments.
\end{abstract}

Keyword : PCBK, SPB 


\section{PENDAHULUAN}

Kemajuan ilmu pengetahuan dan teknologi yang begitu pesat, mendorong sektor pendidikan untuk terus meningkatkan kualitas guru dan calon guru pada setiap jenjang pendidikan. Guru berkualitas diharapkan memiliki empat kompetensi yakni. (1) Kompetensi profesional, yaitu kemampuan menguasai materi pembelajaran secara luas dan mendalam. (2) Kompetensi kepribadian, yaitu kemampuan personal yang menunjukkan kepribadian stabil, dewasa, berwibawa, memberikan keteladanan, dan berakhlak mulia. (3) Kompetensi pedagogik, yaitu kemampuan memahami siswa, merancang dan melaksanakan pembelajaran, mengevaluasi hasil belajar, dan mengembangkan berbagai potensi siswa. (4) Kompetensi sosial, yaitu kemampuan guru untuk berkomunikasi dan bergaul secara efektif (UU Nomor 14 tahun 2005).

Kemampuan pedagogik (pedagogical knowledge) penting dalam proses pembelajaran, dalam hal ini guru harus mampu menyiapkan dan melaksanakan pembelajaran berkualitas. Kemampuan pedagogik harus dilatih secara berkesinambungan sehingga menjadi pengetahuan dan keterampilan bagi guru profesional. Guru dan calon guru perlu diberi bekal pengetahuan dan keterampilan dalam mendesain, mengelola kelas yang efektif, memilih dan memanfaatkan media dan sumber belajar, mampu mengembangkan instrumen penilaian, mengembangkan materi ajar (conten knowledge) yang tertuang dalam rancangan rencana pembelajaran (Ernawati, 2017).

$$
\text { Penguasaan konsep content }
$$

knowledge bagi guru dan calon guru yang profesional sama pentingnya dengan kemampuan dalam penguasaan pedagogical knowledge. Pedagogical and Content Knowledge (PCK). merupakan sebuah kerangka konseptual gabungan dari kemampuan merancang dan menyampaikan materi pembelajaran secara tepat dengan konsep materi yang benar (Mishra, 2006). Menurut Marzano (2012) "Framework 21st century learning", menggambarkan bahwa ada empat aspek yang harus dimiliki oleh seorang lulusan sekolah, yaitu (1) Subjek dan tema inti, (2) Keterampilan pembelajaran dan inovasi, (3) Keterampilan informasi, media dan teknologi, (4) Kecakapan hidup dan karier. Kualitas lulusan yang diharapkan tersebut, berkaitan dengan kompetensi guru sebagai fasilitator pembelajaran. Dengan demikian kompetensi PCK merupakan salah satu upaya tercapainya kualitas lulusan sesuai dengan tuntutan pendidikan abad 21.

Berlandaskan pada framework 21st century learning pola pengembangan kompetensi mahasiswa calon guru, salah satunya mahasiswa pendidikan biologi adalah menguasai strategi pembelajaran dan materi ajar biologi. Faktor yang dapat meningkatkan kemampuan guru dalam meningkatkan kemampuan PCK yaitu memberikan penguatan pada pengusaan konsep materi (subject matter) dan menyampaikan materi tersebut secara tepat sesuai dengan tingkat perkembangan peserta didik (Loughran, 2001). Menurut Mercado (2015) metode perkuliahan pendidikan keguruan (preservice teacher) harus mengembangkan pemahaman tentang Nature of Science (NoS). Aspek yang terkait dalam NoS antara lain bersifat empiris, melibatkan imajinasi dan kreativitas, mempengaruhi dan dipengaruhi oleh aspek sosial dan budaya (Loughran, 2008). Pendapat tersebut memberikan penguatan bahwa guru sains yang di dalamnya termasuk mahasiswa pendidikan biologi harus memiliki kemampuan Pedagogical and Content 
Biology Knowledge (PCBK) yang baik, guna menunjang .

Implementasi kemampuan PCBK bagi mahasiswa Program Studi Pendidikan Biologi (P.BIO) antara lain dilakukan pada mata kuliah Startegi Pembelajaran Biologi (SPB). Materi perkuliahan SBP di Prodi Pendidikan Biologi memberi bekal mendasar kepada mahasiswa tentang metode, teknik, dan pemanfaatan sumber belajar untuk mencapai tujuan pembelajaran yang telah ditetapkan. menganalisis materi pembelajaran, menentukan dan merancang pengalaman belajar yang sesuai dengan karakteristik materi dan tujuan pembelajaran, menentukan pendekatan dan metode sesuai dengan karakteristik materi dan tujuan pembelajaran. Kompetensi yang telah dimiliki diharapkan mahasiswa mampu mengaplikasikan strategi-strategi tersebut dengan baik di dalam pembelajaran agar tujuan yang diharapkan dalam pembelajaran dapat tercapai sesuai dengan tujuan pembelajaran. PCK merupakan konsep berpikir yang memberikan pengertian bahwa untuk mengajar biologi tidak cukup hanya memahami konten materi tetapi juga strategi pembelajaran yang dikembangkannya.

Berdasarkan uraian di atas sangat menarik untuk menganalisis profil PCK mahasiswa Pendidikan Biologi dalam merancang rencana pembelajaran. Kemampuan PCK dapat dianalisis berdasarkan dari pemilihan model dan metode yang tepat sesuai dengan konsep materi materi dan tujuan pembelajaran yang dirumuskan dalam rencana pembelajaran. Indikator kemampuan PCK merujuk pada prinsip prinsip Content Representation (CR) dan Pedagogical and Professional-Experience Repertoire (PPER) (Loughran, 2001). Indikator CR-PPER dapat menggambarkan kemampuan mahasiswa dalam merancang pembelajaran sehingga dapat dijadikan umpan balik untuk mengembangkan materi dan proses perkuliahan yang terkait mata kuliah SPB pada Prodi Pendidikan Biologi.

\section{METODE}

Penelitian ini merupakan penelitian deskriptif untuk mendeskripsikan kemampuan PCBK mahasiswa Prodi Pendidikan Biologi. Subjek penelitian ini adalah mahasiswa yang menempuh mata kuliah SPB pada semester genap tahun 2019/2020, berjumlah 64 orang pada dua rombongan belajar. Instrumen PCBK yang digunakan diadaptasi dari CR dan PPER (Loughran, 2001). Komponen untuk mengukur kemampuan PCBK berdasarkan pada kemampuan mahasiswa dalam merancang rencana pembelajaran. Aspek yang dinilai mencakup kemampuan merumusan indikator, merumuskan tujuan pembelajaran, menentukan model dan metode pembelajaran, merumuskan konsep materi ajar biologi, dan merancang aktivitas pembelajaran. Data kompetensi PCBK dianalisis secara deskriptif yang dikonversi menjadi lima kategori sangat baik, baik, cukup, kurang, dan sangat kurang.

Ketercapaian kemampuan mahasiswa dalam merancang rencana pembelajaran merujuk pada ketercapaian mata kuliah SPB. Capaian minimal untuk mata kuliah SPB adalah mahasiswa harus menapai nilai 70 dari skala 0-100. Jika nilai minimal belum tercapai, maka konsep PCBK yang dituangkan dalam rencana pembelajaran belum dapat dipahami secara utuh oleh mahasiswa sebagai subjek penelitian. 


\section{HASIL DAN PEMBAHASAN}

Berdasarkan hasil penelitian diketahui sebagian besar mahasiswa Pendidikan Biologi memiliki nilai di atas skor minimal (70) mencapai $78,12 \%$ dan dibawah skor minimal 21,87\%. Persentase tersebut menunjukan bahwa kemampuan PCBK mahasiswa dalam menyusun rencana pembelajaran sudah tercapai ( $\geq 70 \%$ ). dengan rata-rata skor mencapai 70,2 termasuk dalam kategori baik. Hasil analisis tersebut menggambarkan secara umum mahasiswa telah memahami penyusunan rencana pembelajaran dengan baik. Sebaran kemampuan mahasiswa setiap kategori dapat dilihat pada Gambar 1.

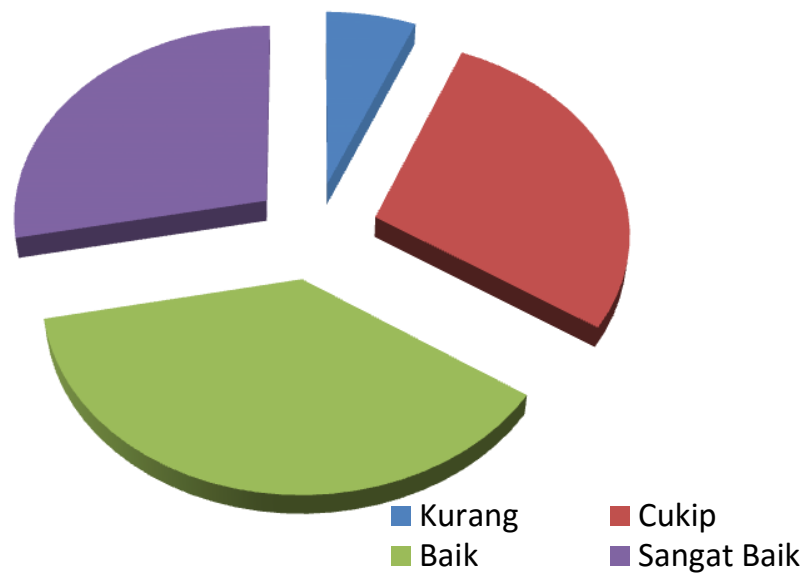

Gambar 1. Kemampuan Mahasiswa Pendidikan Biologi dalam Merancang Perencanaan Pembelajaran Biologi

Berdasarkan hasil analisis menunjukkan persentase kemampuan PCBK mahasiswa Pendidikan Biologi yang termasuk kategori kurang mencapai $6,25 \%$ dan tidak ditemukan mahasiswa yang berkategori sangat kurang. Sebagian besar mahasiswa memiliki kemampuan PCK berkategori cukup sebesar 37,50, sedangkan kategori baik dan sangat baik masing masing $28,13 \%$.
Ketercapaian PCBK berdasarkan komponen kemampuan merumusan indikator, merumuskan tujuan pembelajaran, menentukan model dan metode pembelajaran, merumuskan konsep materi ajar biologi, dan merancang aktivitas pembelajaran dapat dilihat pada Gambar 2.

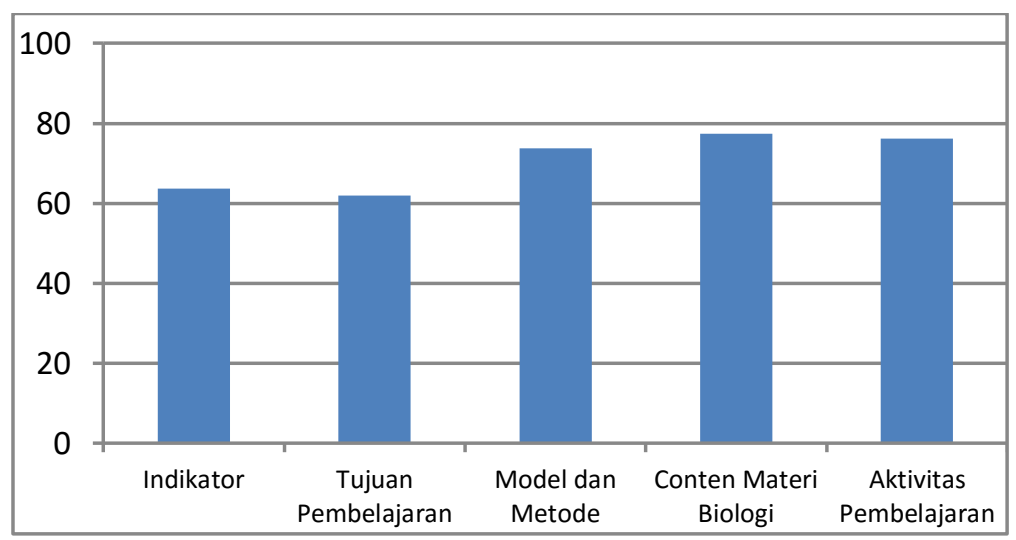

Gambar 2 Kemampuan Mahasiswa Pendidikan Biologi Berdasarkan Komponen Perencanaan Pembelajaran 
Berdasarkan Gambar 2, komponen rumusan indikator dan tujuan pembelajaran masing-masing mencapai $63,75 \%$ dan $61,75 \%$. Persentase tersebut menggambarkan bahwa kemampuan mahasiswa dalam merumuskan indikator dan tujuan pembelajaran belum memenuhi kriteria ketercapaian ( $\geq 70 \%$ ). Komponen model dan metode pembelajaran, konten materi dan aktivitas pembelajaran masing-masing mencapai $74,75 \%, 77,50 \%$, dan 76,25. Hasil analisis tersebut menggambarkan bahwa kemampuan mahasiswa dalam menentukan model dan metode pembelajaran, mengembangkan konten materi ajar biologi, dan merancang aktivitas pembelajaran telah mencapai kriteria ketercapaian ( $\geq 70 \%)$. Pemahaman mahasiswa dalam merumuskan indikator dan tujuan pembelajaran masih kurang dibandingkan dengan kemampuan mengembangkan konten materi ajar dan menentukan strategi pembelajaran dalam perencanaan pembelajaran.

Hasil analisis diketahui bahwa komponen rumusan indikator dan tujuan pembelajaran belum mencapai kriteria ketercapaian ( $\geq 70 \%$ ). Berdasarkan 5 aspek indikator penilaian dari kedua komponen tersebut, menunjukkan bahwa kemampuan mahasiswa sangat bervariasi. Ketercapaian dalam merumuskan indikator dan tujuan pembelajaran dari setiap aspek indikator penilaian dapat dilihat pada Tabel 1.

Tabel 1. Persentase Kemampuan Mahasiswa Pendidikan Biologi dalam Merumuskan Indikator dan Tujuan Pembelajaran

\begin{tabular}{cccccccc}
\hline & & \multicolumn{4}{c}{ Aspek Indikator Penilaian (\%) } & \multicolumn{2}{c}{$\begin{array}{c}\text { Rata- } \\
\text { No }\end{array}$} \\
\cline { 3 - 8 } & Komponen & A & B & C & D & E & \\
\hline 1 & Rumusan Indikator & 65,6 & 65,6 & 68,8 & 59,4 & 59,4 & 63,75 \\
2 & Tujuan Pembelajaran & 21,9 & 59,4 & 59,4 & 71,9 & 96,9 & 61,75 \\
\hline
\end{tabular}

Persentase setiap aspek indikator penialaian untuk komponen rumusan indikator yang mencakup $(A)$ merumuskan berbagai jenjang kognitif, (B) merumuskan aspek psikomotor dan atau afektif, (C) mengembangkan pengetahuan faktual, konseptual, dan atau prosedural, (D) menggunakan Kata Kerja Operasional (KKO) dapat diukur, (E) KKO tidak memiliki makna ganda menunjukkan bahwa kelima aspek penilaian merumusan indikator masih belum memenuhi ketercapaian minimal ( $\geq 70 \%$ ). Pada Tabel 1 menunjukkan bahwa persentase ketercapaian aspek indikator penilaian $A$ dan B masing-masing 65,6\%, aspek C mencapai $68,8 \%$, sedangkan aspek $D$ dan
E masing-masing 59,4\%. Hasil analisis menggambarkan rumusan indikator yang disusun oleh mahasiswa belum membuat rumusan indikator dari berbagai jenjang kognitif yang lebih tinggi ( $C 4, C 5$, atau $C 6)$, dan rumusan aspek psikomotor atau afektif. Rumusan indikator lebih lebih banyak mengembangkan pengetahuan yang sifat konseptual, tetapi sangat minim mengembangkan pengetahuan faktual dan prosedural. Dalam merumuskan indikator masih banyak ditemukan penggunaan kata kerja yang tidak dapat diukur dan memiliki makna ganda.

Indikator Pencapaian Kompetensi (IPK) atau lebih sering dikatakan indikator pembelajaran adalah salah satu 
komponen penting dalam analisis materi pelajaran. IPK dimaksudkan untuk menjadi acuan dalam penilaian pada mata pelajaran yang terdiri atas dan merupakan tolak ukur ketercapaian suatu kompetensi dasar (Dwiyanti, 2011). Beberapa hal yang menjadi acuan dalam merumuskan IPK, adalah melihat kedudukan Kompetensi Dasar, menentukan dimensi pengetahuannya, menggunakan kata kerja operasional yang sesuai. Dengan demikian rumusan indikator sangat penting dilakukan untuk mempermudah guru dalam mencapai tujuan pembelajaran.

Tujuan pembelajaran merupakan penjabaran lebih rinci dari indikator dengan mengaitkan dimensi yang akan dikembangkan. Merujuk pada 3 aspek indikator penilaian dalam merumuskan tujuan pembelajaran rumusan indikator, meliputi (A) rumusan tujuan menggambarkan proses sesuai metode/model yang direncanakan, (B) menggunakan Kata Kerja Operasional (KKO) yang dapat diukur, (C) minimal merumuskan 2 aspek pengetahuan, psikomotorik, dan atau sikap, masih belum memenuhi ketercapaian minimal $(\geq$ 70\%). Persentase dari ketiga aspek penilaian untuk aspek $A$ hanya mencapai 21,9\%, sedangkan B dan C mencapai $59,4 \%$. Hasil analisis pada rumusan tujuan pembelajaran, mahasiswa masih belum mampu menentukan model atau metode pembelajaran yang tepat dan sesuai dengan tuntutan kompetensi dasar yang ingin dicapai. Pada setiap butir rumusan tujuan pembelajaran belum tergambarkan proses atau metode yang dilakukan dalam mencapai tujuan tersebut. Rumusan tujuan pembelajaran lebih banyak aspek pengetahuan dan sangat kurang mengembangkan aspek sikap. Kondisi ini juga ditemukan pada rumusan indikator pembelajaran yang lebih banyak menekankan aspek kognitif. Pada aspek (D) yaitu setiap butir rumusan tujuan pembelajaran minimal memenuhi 3 komponen audience, behavior, conditioning, atau degree, dan aspek (E) semua rumusan tujuan pembelajaran rumusan memiliki keterkaitan dengan indikator dan atau KD, masing-masing $71,9 \%$ dan $96,9 \%$. Kemampuan mahasiswa pada kedua aspek ini ( $D$ dan E) telah memenuhi ketercapaian minimal ( $\geq 70 \%)$, hal tersebut menggambarkan sebagian besar mahasiwa sudah mampu merumuskan kemampuan tujuan pembelajaran secara tepat dengan menghubungkan antara indikator dan tujuan pembelajaran yang akan dicapai. Rumusan tujuan pembelajaran harus memperhatikan unsur-unsur yang terdapat dalam tujuan pembelajaran, dimulai dengan mencantumkan Audience (A) yakni peserta didik, Behavior (B) yaitu perubahan perilaku yang diharapkan oleh peserta didik setelah mengikuti pembelajaran, Condition (C) yaitu aktivitas yang akan dilakukan atau kemampuan yang akan diamati, dan Degree (D) yaitu tingkatan/perilaku yang diharapkan yang dapat berbentuk kecepatan, ketepatan, kuantitas atau kualitas. Indikator pencapaian kompetensi sebagai target kemampuan yang akan dicapai pada tujuan pembelajaran, maka tujuan pembelajaran harus searah dengan target yang akan dicapai dan memfasilitasi peserta didik agar dapat mencapai kemampuan yang dirumuskan pada indikator.

Hasil analisis diketahui bahwa kemampuan mengembangkan komponen model dan metode, konten materi ajar, dan aktivitas pembelajaran telah memenuhi kriteria ketercapaian minimal ( $\geq 70 \%$ ), dapat di lihat pada Gambar 2 . Gambaran umum dari ketiga komponen tersebut, masih terdapat aspek indikator penilaian yang di bawah ketercapaian minimal. Ketercapaian ketiga komponen tersebut ditunjukkan pada Tabel 2. 
Tabel 2 Persentase Kemampuan Mahasiswa Pendidikan Biologi dalam Merumusan Model dan Metode Pembelajaran, Konten Materi Ajar, dan Aktivitas Pembelajaran

\begin{tabular}{lllccccc}
\hline \multirow{2}{*}{ No } & Komponen & \multicolumn{4}{c}{ Aspek Indikator Penilaian (\%) } & Rata- \\
\cline { 3 - 6 } & & A & B & C & D & E & rata \\
\hline 1 & Model dan Metode & 81,25 & 68,75 & 71,88 & 84,38 & 62,50 & 74,75 \\
2 & Konten Materi Aar & 73,78 & 78,13 & 90,63 & 87,50 & 62,50 & 77,50 \\
3 & Aktivitas Pembelajaran & 96,88 & 78,13 & 46,88 & 65,63 & 93,75 & $76,25$. \\
\hline
\end{tabular}

Kemampuan mahasiswa dalam menentukan Model dan Metode pembelajaran yang masih rendah adalah aspek B yaitu ketepatan pemilihan metode dengan tujuan, dan proses, dan aspek $\mathrm{E}$ yaitu mengembangkan pembelajaran yang berorientasi pada 3 kemampuan berpikir kritis, kreatif, komunikatif dan atau kolaboratif (4K). Masing-masing kedua aspek tersebut belum memenhi kriteria ketercapaian minimal $(\geq 70 \%$ ) dengan rata-rata skor 68,75 dan 62,50. Sedangkan aspek ketepatan pemilihan model dengan indikator/KD (A), keterkaitan antara model dan metode (C), dan kesesuaian metode dengan materi (D) telah memenuhi ketercapaian kriteria minimal. $\mathrm{Hal}$ ini menggambarkan secara umum bahwa mahasiswa telah memiliki kemampuan dalam menentukan model dan metode yang tepat.

Pemilihan model dan metode pembelajaran harus memperhatikan tujuan pembelajaran yang hendak dicapai, sifat materi yang akan diajarkan, karakteristik dan kemampuan peserta didik serta sumber-sumber belajar. Menurut Nurdiansyah (2016), sebelum menentukan model pembelajaran yang akan digunakan dalam kegiatan pembelajaran ada beberapa hal yang perlu dipertimbangkan guru seperti, pertimbangan terhadap tujuan pembelajaran yang akan dicapai berkenaan dengan domain kognitif, afektif, dan psikomotorik, pertimbangan terhadap bahan atau materi pelajaran yang akan digunakan, kondisi peserta didik berkenaan dengan model dan metode yang digunakan apakah sesuai dengan kebutuhan dan karakteristik peserta didik. Metode pembelajaran adalah cara atau tahapan yang digunakan dalam interaksi antara peserta didik dan guru untuk mencapai tujuan pembelajaran yang telah ditetapkan sesuai dengan materi dan mekanisme metode pembelajaran (Afandi, 2013). Dengan demikian pemilihan model dan metode pembelajaran harus mampu meningkatkan proses dan hasil belajar yang lebih efektivitas atau efisiensi sesuai dengan kebutuhan dan tingkat perkembangan peserta didik.

Kemampuan mahasiswa dalam mengembangkan konten materi ajar pada aspek (A) merumuskan materi pembelajaran dalam beberapa pokok bahasan, (B) merancang sajian materi secara sistematis dan jelas, (C) sajian materi yang menggambarkan hubungan antar konsep, dan (D) keluasan materi dari pokok bahasan yang dirumuskan, telah melebihi kriteria ketercapaian minimal ( $\geq$ 70\%). Sedangkan pada aspek $E$ yaitu kemampuan dalam merumuskan yang Menggambarkan kedalaman materi 
berorientasi problem solving/HOTS (E) masih belum mencapai kriteria ketercapaian minimal. Pembelajaran yang berorientasi pada HOTS didasarkan pada tuntutan kurikulum yang berorientasi pada pendidikan abad 21 (Ariyana, 2019). Selain mengetahui materi/bahan ajar yang akan dibelajarkan, seorang guru harus memahami dan mampu mengintegrasikan subjeck matter (materi ajar) ke dalam pembelajaran. Penguasaan materi ajar tersebut dapat menuntun guru untuk merangkai situasi pembelajaran sesuai kebutuhan individual dan kelompok siswa (Kartal, 2012). Pemahaman konten materi ajar disebut sebagai pengetahuan konten (content knowledge) yang dipadukan dengan pengetahuan pedagogik (pedagogic knowledge) atau disebut pedagogic content knowledge (NRC,1996. Evens, 2015).

Komponen aktivitas pembelajaran secara umum sudah memenuhi ketercapaian kriteria minimal, aspek yang paling tingi dari komponen ini yaitu kemampuan mahasiswa dalam (A) memberikan acuan/menggali pengetahuan awal sesuai materi, (B) memberikan gambaran pembelajaran berpusat pada siswa, dan (E) mengambarkan review atau penguatan konsep. Masing-masing setiap aspek mencapai rata persetase $96,88 \%, 78,13 \%$, dan 93,75\%, hal ini menggambarkan bahwa mahasiswa telah mampu merancang dalam membuka dan menutup pembelajaran, serta merancang pembelajaran yang berpusat pada siswa secara konseptual. Kemampuan ini tidak sejalan dengan kemampuan mahasiswa dalam aspek (C) merancang langkah langkah pembelajaran sesuai dengan model/metode dan (D) menggambarkan proses pembelajaran yang beroreinasi HOTS, kedua aspek tersebut (C dan D) berada dibawah kriteria ketuntasan minimal. Kompetensi mahasiswa dalam merancang langkah-langkah pembelajaran terkait dengan pemahaman langkahlangkah (sintaks) model dari setiap pembelajaran. Setiap langkah pembelajaran berhubungan dengan proses pembelajaran yang mendorong pembelajaran yang berorientasi pada kemampuan berpikir tingkat tinggi.

Terkait dengan pengetahuan dan kemampuan dalam mengembangkan pembelajaran yang berorientasi pada siswa dan berpikir tingkat tinggi berkaitan dengan kemampuan dalam menggali informasi dan pemanfaatan teknologi. Pemanfaatan pengetahuan teknologi informasi adalah pengetahuan tentang bagaimana menggunakan perangkat keras dan lunak TIK sebagai alat pembelajaran (Chai, 2013). Beberapa tahun terakhir teknologi telah memainkan peran penting dalam mengubah pendidikan menjadi kegiatan yang lebih progresif dan interaktif, guru harus kompeten dalam pengetahuan subjek, keterampilan pedagogis dan pengetahuan teknologi (Khine, et al., 2017). Lebih lanjut Chai, et al (2013) menjelaskan ketika pengetahuan teknologi diintegrasikan dengan unsur TPACK maka akan muncul TPK, TCK, dan TPACK. TPK merupakan pengetahuan tentang keberadaan dan spesifikasi berbagai teknologi untuk memungkinkan pendekatan pengajaran tanpa referensi terhadap materi pelajaran, contohnya menggunakan TIK sebagai alat kognitif dan pembelajaran kolaboratif didukung komputer.

\section{PENUTUP}

\section{Simpulan dan Saran}

Kemampuan pedagogik dan konten materi biologi mahasiswa pendidikan biologi dalam merancang rencana pembelajaran biologi secara umum sudah baik. Kemampuan pengusaan konten materi biologi dan pemilihan model dan 
metode serta keterkaitan dengan aktivitas pembelajaran telah memenuhi kompetensi yang diharapkan. Kemampuan mahasiswa dalam merumuskan indikator dan tujuan pembelajaran perlu ditingkatkan melalui latihan yang tersruktur dengan memperhatikan capaian kompetensi dasar yang ingin dicapai. Peningkatan kompetensi pedagogik dibutuhkan praktik langsung di satuan pendidikan agar keterampilan yang dibutuhkan untuk menghasilkan tenaga pendidik yang profesional.

\section{DAFTAR PUSTAKA}

Afandi, Muhammad. 2013. Model Dan Metode Pembelajaran Di Sekolah. Semarang: Unissula Press.

Ariyana, Yoki. 2019. Buku Pegangan Pembelajaran Berorientasi pada Keterampilan Berpikir Tingkat Tinggi. Jakarta: Direktorat Jenderal Guru dan Tenaga Kependidikan, Kementerian Pendidikan dan Kebudayaan.

Chai, C.-S., Koh, J. H.-L., \& Tsai, C.-C. (2013). A Review of Technological Pedagogical Content Knowledge. Educational Technology \& Society, $16(2), 31-51$.

Dwiyanti, Gebi. 2011. RPP, Pengembangan Indikator, dan Tujuan Pembelajaran. Bandung: Universitas Pendidikan Indonesia.

Ernawati. 2017. Analisis Kesulitan Guru dalam Merancang Rencana Pelaksanaan Pembelajaran Mata Pelajaran Fisika Berdasarkan Kurikulum 2013 Di Kota Banda Aceh. Jurnal Pendidikan Sains Indonesia. Vol. 5 (2) : 52.
Evens, M., Elen, J. \& Depaepe, F. (2015). Developing Pedagogical Content Knowledge: Lesson Learned from Intervention Studies. Education Research International Vol 2015, Article ID 790417, http://dx.doi.org/10.1155/2015/790 $\underline{417}$.

Kartal, T, Ozturk, N. \& Ekici. (2012). Developing pedagogical content knowledge in preservice science teachers through microteaching lesson study. Procedia-Social and Behavioral Sciences 46 (2012) 27532758.

Khine, M. S., Ali, N. \& Afari, E. (2017). Exploring relationships among TPACK constructs and ICT achievement among trainee teachers. Education and Information Technologies. Volume 22, Issue 4, pp 1605-1621.

Loughran, J., Berry, A., \& Mullhall, P . (2012). Understanding and developing science teacher's pedagogical content knowledge (2nd ed.) Rotterdam: Sense Publisher.

Loughran, J., Milroy, P.Berry, A., Gunstone, R., \& Mullhall, P. (2001). Documenting Science Teachers'Pedagogical Content Knowledge Through PaP-eRs. Research in Science Education, 31, 289307.

Loughran, Pamela Mulhallb \& Amanda Berrya. (2008). Exploring Pedagogical Content Knowledge in Science Teacher Education. International Journal of Science Education Vol. 30, No. 10, 13 August 2008, pp. 1301- 1320. 
Marzano, R. J \& Heflebower, T. (2012). Teaching \& Assssing 21st Century Skills (The Classroom Strategies Series). E_Book from marzanoresearch.com

Mercado, C. T. , F. B. Macayana, L. G. Urbiztondo. 2015. Examining Education Students' Nature of Science (NoS) Views. Asia Pacific Journal of Multidisciplinary Research.3(5).p.101-110.

Mishra, P. dan M. J. Koehler. (2006). Technological Pedagogical Content Knowledge: A Framework for Teacher Knowledge. Teachers Colege Record. 6 (108): 1017-1058.

National Research Council. 1996. National Science Education Standard. Washington: National Academy Press.

Nurdyansyah. 2016. Inovasi Model Pembelajaran. Sidoarjo: Nizamia Learning Center

Undang-undang nomor 14 tahun 2005 tentang Guru dan Dosen. Jakarta 